International Journal of Advanced Research in Engineering and Technology (IJARET)

Volume 12, Issue 4, April 2021, pp. 534-549, Article ID: IJARET_12_04_051

Available online at https://iaeme.com/Home/issue/IJARET?Volume $=12 \&$ Issue $=4$

ISSN Print: 0976-6480 and ISSN Online: 0976-6499

DOI: https://doi.org/10.34218/IJARET.12.4.2021.051

C IAEME Publication

Scopus Indexed

\title{
OPPORTUNITIES AND PROBLEMS OF WOMEN DIGITAL ENTREPRENEURS IN INDIA DURING COVID-19 PANDEMIC
}

\author{
G. Lakshmi Priya1, Dr. S. Smilee Bose ${ }^{2}$ \\ ${ }^{1}$ Full-Time Research Scholar, Department of Commerce, \\ St. Peter's Institute of Higher Education and Research, \\ St. Peters University, Tamil Nadu, India \\ ${ }^{2}$ Research Supervisor, Associate Professor, Department of Commerce, \\ St. Peter's Institute of Higher Education and Research, \\ St. Peters University, Tamil Nadu, India
}

\begin{abstract}
Year 2020 has become reminded in history as it is a Humanitarian disaster because of spread of Corona Virus Disease- 2019 which has influenced every lives of the World. Various preventive measures have been taken by the Government to limit Corona Virus transmission as there was a huge disruption to Women Entrepreneurship not only socially but also economical shutdown among Small-Scale business.

Now offline shopping becomes difficult as well as risky among people. This made Entrepreneurs to take advantage of internet technology for survival in their business. This Pandemic compelled many Women Entrepreneurs and their start-ups to tenure employees which leads to unemployed and result in lack of productivity, decrease in revenue and contraction of economy worldwide. All this affected self-employed Women Entrepreneurs and pushed them to online platforms.

Women Entrepreneurs have not only faced many challenges in adapting new medium of business during COVID-19 pandemic. At the same time, COVID-19 has provided opportunities for them as growing use of digital technology means cheaper and greater access, better coordination, higher productivity and lower costs which allows women to exploit these advantage of technology and market needs. This paper discuss about opportunities of Women Entrepreneurs in COVID-19 and challenges faced by them during COVID-19 pandemic. For this, survey has been conducted among hundred Women Entrepreneurs doing Digital Business in Tamil Nadu and conducted via personal Google form link.
\end{abstract}

Key words: Covid-19, Pandemic, Lockdowns, Digital Business, Women Digital Entrepreneurs, Opportunities, Challenges. 
Cite this Article: G. Lakshmi Priya and S. Smilee Bose, Opportunities and Problems of Women Digital Entrepreneurs in India during Covid-19 Pandemic, International Journal of Advanced Research in Engineering and Technology, 12(4), 2021, pp. 534-549.

https://iaeme.com/Home/issue/IJARET?Volume=12\&Issue $=4$

\section{INTRODUCTION}

The initialization of lockdown during COVID-19 pandemic has made dynamic changes in the business all over the world. The difficulties faced by business entrepreneurs during COVID-19 are reducing the creation of their start-ups, challenge in their survival and limiting their growth. All these made entrepreneurs to adjust with digital solutions

Women Entrepreneurs are considered as life-blood of our Indian economy as their contribution towards economy has been significantly increasing at considerable rate. Women Entrepreneurs have faced difficulty caused by Corona Virus Disease -2019 both economically as well as family responsibilities. Though the Women are facing increased unemployment and home responsibilities there are new changes accelerated such as acceptance and increase in use of digital platforms to reach out mass people as possible which will boost their business. These changes have resulted in success of Women Entrepreneurs.

Inspite of number of Women Entrepreneur's new business registration generally drops during COVID-19 recession, there are many successful innovative Women Entrepreneurs have immediately reacted to this pandemic by shifting towards digital work, education and health services and have provided innovations in goods and services. Women Entrepreneurs seized this situation as a opportunity to launch their business digitally with the objective of achieving financial growth as well as economic growth.

In the era of COVID-19, social networking platforms like Face Book, Whatsapp, Instagrams, E-mails etc. have become exclusive marketing tools for Women Entrepreneurs which enables them to maintain a connect with their existing customer base. Now Digital mode of payment like net banking, card payment, paytm. UPI, G-pay etc has become imperative in our country.

COVID-19 pandemic has made Women Entrepreneurs difficult in creating employment, decrease in revenue and demand of products and services, lack of workforce and less productivity. Today, this crisis provided opportunities for Women Entrepreneurs in Telemedicine, online food delivery, online tutoring, online medical services etc,. Therefore, this paper aims to provide valuable insights of opportunities of Women Digital Entrepreneurs and problems faced by Women Digital Entrepreneurs during COVID-19.

\section{OBJECTIVES OF THE STUDY}

1. To Examine opportunities faced by Women Digital Entrepreneurs during COVID-19 pandemic.

2. To Determine the challenges faced by Women Digital Entrepreneurs during COVID-19 pandemic.

\section{REVIEW OF LITERATURE}

J.Premadas (October- December 2020)- " Negative Impact of COVID-19 in the life of Charcoal Entrepreneurs". This study highlighted the problems faced by entrepreneurs in Wood charcoal business enterprises during COVID-19 pandemic. The Researcher discussed about the changing consumption pattern of their customers to use of online technology like online 
shopping, online food delivery, video conferencing which creates opportunities for entrepreneurs to increase the touch points with their customer during COVID-19 pandemic.

Madhavilatha Sangem (November 2020)- "Challenges for Women Entrepreneurs in the wake of COVID-19 Pandemic". This study explored the challenges of women Entrepreneurs during COVID-19. The Researcher discussed about the change in new business models with the adoption on digital technology for accessing their business operation during COVID-19. She indicated two factors for increasing their Revenue during CoronaVirus Lockdown :

1. Increase in the sale of necessary products and services during COVID-19 Pandemic and

2. Realignment of Business Model to adjust with Coronavirus scenario.

Tatiana S Manolova, Candida G Brush, Linda F Edleman (October 2020)- "Pivoting to stay the course: How Women Entrepreneurs take advantage of opportunities created by the COVID19 Pandemic. This study discussed the challenges and opportunities faced by Women Entrepreneurs by recent data surveyed from Diana International Research Institute (DIRI) for indentifying business model pivoting in Women-owned business. From this surveyed data, observed that there are three major challenges faced by Women Entrepreneurs in COVID-19 Pandemic:

a) industries where most women operated are disproportionately affected by the recession.

b) Women are more likely to run many of the youngest, smallest and most vulnerable business.

c) with schools closed during pandemic Women under the threat of being care-taker and homemaker.

This study involves two case studies, women entrepreneurs who pivot their business models to take advantage of the opportunities created from the COVID-19 pandemic

1. Case of Abigai Rose

2. Case of Skida.

The researchers concluded that usage of ICT by micro-entrepreneurs during COVID-19 pandemic was influenced by micro-entrepreneurs' perceptions, of ease of use and usefulness. ICT have direct influence on entrepreneurial self-efficacy and social networking.

\section{RESEARCH METHODOLOGY}

This study is based on both Primary data and Secondary data. Primary data are collected using Questionnaire. Secondary data are collected through Journals, Books, Websites, and Published articles and Magazines related to this topic.

Sample Design: This study has adopted Qualitative approach to examine the status of Women Digital Entrepreneurs during COVID-19 Pandemic. For this, sample of hundred women entrepreneurs doing online business has been taken in and around various Districts of Tamil Nadu. Sampling is done on the basis of simple and stratified random sampling.

This study was conducted between $16^{\text {th }}$ March 2021- $31^{\text {st }}$ March 2021. The survey was conducted via Personal Google form link.

Data Analysing Tools: Data are analysed by using Percentage method and SPSS techniques like One Sample t test, Chi-Square method and Descriptive Statistics.

\section{ANALYSIS AND FINDINGS}

\subsection{Demographic Profile of Women Entrepreneurs}

Demographic factors of Women Entrepreneur's Age, Marital Status, Education Qualification, Experience, Ownership, Business Size and Type of business are analysed using One sample tTest. 
Opportunities and Problems of Women Digital Entrepreneurs in India during Covid-19 Pandemic

\section{Hypothesis}

$\mathrm{H}_{01}: \mu=$ Average age of the respondents belongs to the age group of 20 years -30 years.

$\mathrm{H}_{02}: \mu=$ Average Marital Status of the respondents are Spinster

$\mathrm{H}_{03}: \mu=$ Average Education Qualification of the respondents have Under Graduate Degree

$\mathrm{H}_{04}: \mu=$ Average years of Experience of the respondents have in E-Business is 1year -3 Years.

$\mathrm{H}_{05}: \mu=$ Average number of respondents are Retailers.

$\mathrm{H}_{06}: \mu=$ Average size of the online business is small scale Business

$\mathrm{H}_{07}: \mu=$ Average kind of Business run by the Women Entrepreneurs is Beauty products and cosmetics.

Table 1 Demographic profile of the Respondents

\begin{tabular}{|c|c|c|c|c|c|c|c|c|}
\hline $\begin{array}{c}\text { Demographic } \\
\text { variables }\end{array}$ & $\begin{array}{c}\text { Class } \\
\text { Interval }\end{array}$ & $\begin{array}{c}\text { No. of the } \\
\text { Respondents }\end{array}$ & $\begin{array}{c}\text { Mean } \\
(\overline{\mathbf{x}})\end{array}$ & $\begin{array}{l}\text { Standard } \\
\text { Deviation }\end{array}$ & $\begin{array}{l}\text { Degree of } \\
\text { Freedom }\end{array}$ & $\begin{array}{c}\text { Test } \\
\text { Statistic } \\
T \\
\end{array}$ & $\begin{array}{c}\text { Sig.. } \\
\text { (2Tailed) }\end{array}$ & $\begin{array}{c}\text { Mean } \\
\text { Difference }\end{array}$ \\
\hline \multirow[t]{4}{*}{ Age Group } & \begin{tabular}{|l|} 
Below 20 \\
Years
\end{tabular} & 27 & \multirow{4}{*}{2.16} & \multirow{4}{*}{0.961} & \multirow{4}{*}{99} & \multirow{4}{*}{1.665} & \multirow{4}{*}{0.099} & \multirow{4}{*}{0.160} \\
\hline & \begin{tabular}{|l|}
20 Years- 30 \\
Years
\end{tabular} & 42 & & & & & & \\
\hline & $\begin{array}{l}30 \text { Years- } 40 \\
\text { Years }\end{array}$ & 19 & & & & & & \\
\hline & \begin{tabular}{|l|} 
Above 40 \\
Years
\end{tabular} & 12 & & & & & & \\
\hline \multirow[t]{4}{*}{ Marital Status } & Married & 61 & \multirow[b]{4}{*}{1.48} & \multirow[b]{4}{*}{0.65874} & \multirow[b]{4}{*}{99} & \multirow[b]{4}{*}{-7.894} & \multirow[b]{4}{*}{.000} & \multirow[b]{4}{*}{-0.52000} \\
\hline & Spinster & 30 & & & & & & \\
\hline & Widow & 9 & & & & & & \\
\hline & Divorcee & 0 & & & & & & \\
\hline Education & SSLC/HSC & 6 & \multirow{4}{*}{2.25} & \multirow{4}{*}{0.68718} & \multirow{4}{*}{99} & \multirow{4}{*}{3.368} & \multirow{4}{*}{.000} & \multirow{4}{*}{0.25000} \\
\hline \multirow[t]{3}{*}{ Qualification } & \begin{tabular}{|l|} 
Under \\
Graduate \\
\end{tabular} & 71 & & & & & & \\
\hline & \begin{tabular}{|l|} 
Post \\
Graduate \\
\end{tabular} & 15 & & & & & & \\
\hline & Professional & 8 & & & & & & \\
\hline \multirow{4}{*}{$\begin{array}{l}\text { Experience in E- } \\
\text { Business }\end{array}$} & $0-1$ year & 49 & \multirow{4}{*}{1.83} & \multirow{4}{*}{0.92174} & \multirow{4}{*}{99} & \multirow{4}{*}{-1.844} & \multirow{4}{*}{0.068} & \multirow{4}{*}{-0.17000} \\
\hline & $\begin{array}{l}1 \text { year- } 3 \\
\text { years }\end{array}$ & 22 & & & & & & \\
\hline & $\begin{array}{l}3 \text { years- } \\
5 \text { years }\end{array}$ & 26 & & & & & & \\
\hline & $\begin{array}{l}\text { Above } 5 \\
\text { years }\end{array}$ & 3 & & & & & & \\
\hline \multirow[t]{4}{*}{$\begin{array}{l}\text { Ownership } \\
\text { Structure }\end{array}$} & $\begin{array}{l}\text { Sole } \\
\text { Proprietor }\end{array}$ & 41 & \multirow{4}{*}{1.95} & \multirow{4}{*}{0.98857} & & & & \\
\hline & Retailers & 33 & & & & & & \\
\hline & Partnership & 16 & & & 99 & -0.506 & 0.614 & -0.05000 \\
\hline & $\begin{array}{l}\text { Co- } \\
\text { Operative }\end{array}$ & 10 & & & & & & \\
\hline Size of Business & $\begin{array}{l}\text { Micro level } \\
\text { Business }\end{array}$ & 40 & & & & & & \\
\hline & $\begin{array}{l}\text { Small Scale } \\
\text { Enterprises }\end{array}$ & 33 & 1.90 & 0.87039 & 99 & -1.149 & 0.253 & -0.10000 \\
\hline & $\begin{array}{l}\text { Medium } \\
\text { scale } \\
\text { Enterprises }\end{array}$ & 24 & & & & & & \\
\hline & $\begin{array}{l}\text { Large Scale } \\
\text { Enterprises }\end{array}$ & 3 & & & & & & \\
\hline $\begin{array}{l}\text { Kinds of } \\
\text { Business }\end{array}$ & $\begin{array}{l}\text { Online } \\
\text { Marketing }\end{array}$ & 17 & & & & & & \\
\hline & \begin{tabular}{|l} 
Clothing and \\
Accessories
\end{tabular} & 13 & & & & & & \\
\hline & \begin{tabular}{|l|} 
Online \\
teaching
\end{tabular} & 14 & & & & & & \\
\hline
\end{tabular}


G. Lakshmi Priya and S. Smilee Bose

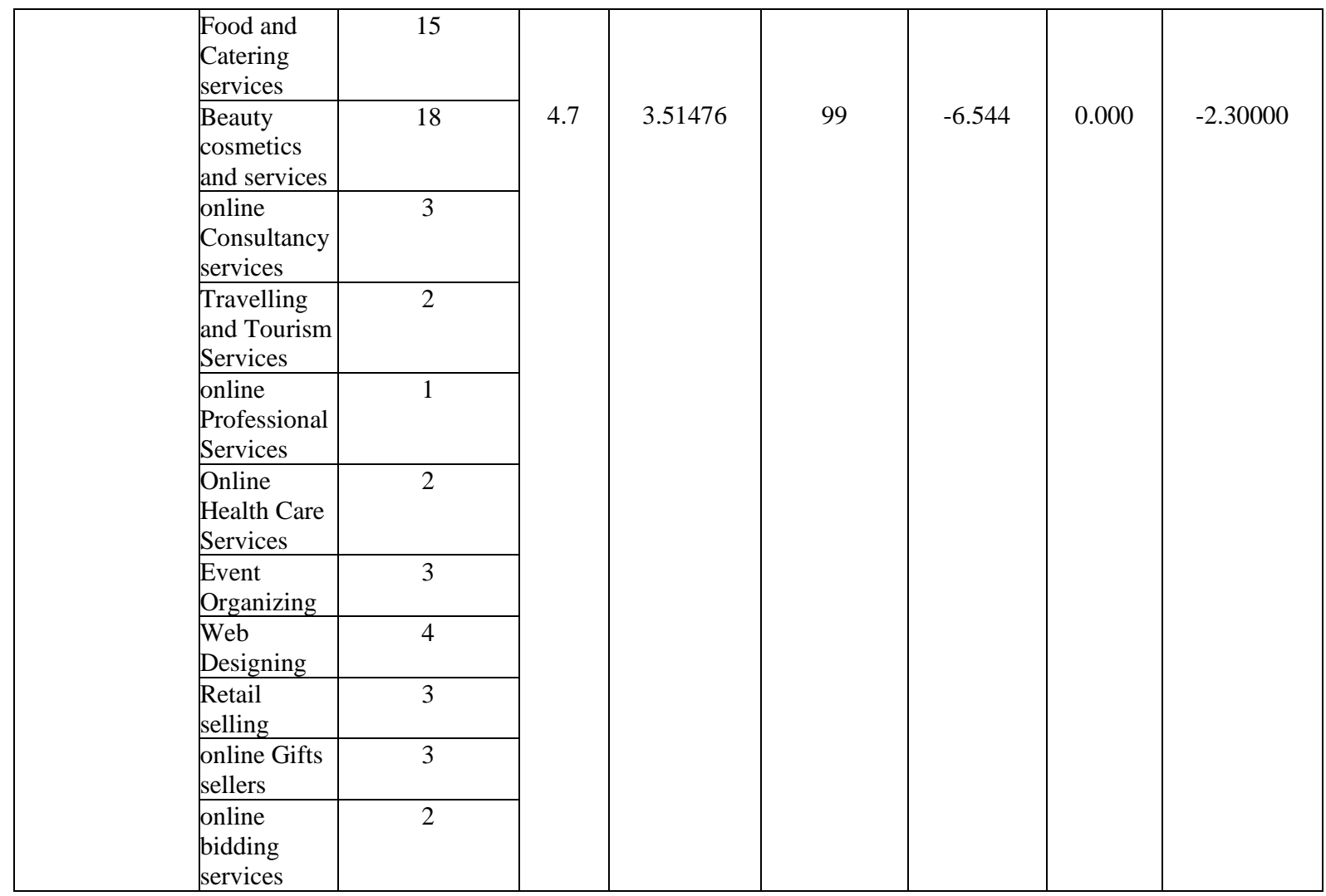

(source: Primary)

Age of the surveyed respondents varied from below 20 years to above 40 years. Age of the respondents are categorized as below 20 years, 20- 30 years, 30-40 years and above 40 years. The frequency distribution of surveyed Women Entrepreneurs in terms of age has been shown in table 1.1. Since the p value (0.099) is More than (>) 0.05. Null Hypothesis $\left(\mathrm{H}_{0}\right)$ is Accepted at $5 \%$ level. Hence, Average age of the respondents belong to the age group of 20 years- 30 Years.

Marital status plays an important role in the field of male domination. The factors like worklife balance and family support depend of marital status of women. The marital status of the respondents are categorised into Married, Spinster, Widow and Divorcee. Since the p value $(0.000)$ is less than $(<)$ 0.05. Null Hypothesis $\left(\mathrm{H}_{0}\right)$ is Rejected at $5 \%$ level. Hence, Average Marital Status of the Respondents are Married.

Education Qualification is considered as important factor because education helps in acquiring knowledge and skills. It is considered as asset of an individual in building their career. Education Qualification of the respondents are categorised as SSLC/HSC, Under Graduate, Post Graduate and Professional. Since the p value $(0.000)$ is less than $(<)$ 0.05. Null Hypothesis $\left(\mathrm{H}_{0}\right)$ is Rejected at 5\% level. Hence, Average Education Qualification of the Respondents does not have Under Graduate Degree.

Experience determines one's own ability in success. It is considered as important factor because it helps to make decision and create confidence in performing business activities. The frequency distribution of Women Entrepreneurs in terms of experience are classified into below one year, 1-3 years, 3-5 years and above 5 years. Since the p value $(0.068)$ is more than $(>)$ 0.05. Null Hypothesis $\left(\mathrm{H}_{0}\right)$ is Accepted at $5 \%$ level. Hence, Average years of Experience of the respondents have in E-Business is 1year -3 Years.

Ownership structure of business include control of business, managerial ability, cost of formation, liability exposure and tax consideration. Ownership structure of the respondent's 
business are classified as sole proprietor, partnership, co-operative business and retail business. Since the p value (0.614) is more than (>) 0.05. Null Hypothesis $\left(\mathrm{H}_{0}\right)$ is Accepted at $5 \%$ level.. Hence, Average number of respondents are Retailers.

Size of business refers to scale of business and volume of business operation. It is depend on the number of employees in business. Size of business of the respondent's business are categorized as micro level business, small scale business, medium level business and large scale business. Since the p value (0.253) is more than (>) 0.05. Null Hypothesis $\left(\mathrm{H}_{0}\right)$ is Accepted at $5 \%$ level.. Hence, Average size of the online business is small scale Business.

Various forms of business is a key factor for determining the economic performance of Women Entrepreneurs. Women Entrepreneurs chooses the type of business according to their skills, knowledge, education, finances and convenience. Since the p value (0.000) is less than (<) 0.05. Null Hypothesis $\left(\mathrm{H}_{0}\right)$ is Rejected at $5 \%$ level.. Hence, Average kind of Business run by the Women Entrepreneurs is not Beauty products and cosmetics

\section{Interpretation:}

From the above table 1.1, shows that Women in the age group of 20 years -30 Years are more likely to start their own Online Business as compared to Women in the Age of Below 20 Years and 30 Years- 40 Years and less favourable in the age of above 40 years.

More than half $(61 \%)$ of the Women Entrepreneurs are Married. They are more likely to start their own Online Business after their marriage as compared to Spinster Women Entrepreneurs.

Majority of the Women Entrepreneurs in Online Business are educated in Under Graduate (71\%) followed by Post Graduate (15\%) than in High School (6\%) and Professional Degree (8\%). This shows Women Entrepreneurs has good knowledge in running their E-Business.

The above table indicates that majority of the Women Entrepreneurs in E-Business have less than one year (49\%) of experience. This shows that Women are most likely to start their online business recent times.

Nearly half of the Women Entrepreneurs (41\%) in E-Business are Sole-Proprietors. This shows that Women Entrepreneurs are more likely to be owned and controlled by herself alone.

Most of the Women Entrepreneurs (40\%) have Micro level business. This shows that Women start their business with the idea of minimum investment and maximum profits.

Majority of the Women Entrepreneurs are involved in selling beauty cosmetics and services (18\%) followed by Online marketing (17\%), Food and Catering services (15\%), Online teaching (14\%), Clothing and accessories (13\%) and less involved in Web designing (4\%), Consultancy services (3\%), Event organization (3\%), Retail selling (3\%), Gift selling (3\%), Tourism booking services (2\%), Health care services (2\%), Bidding services (2\%) and Professional services (1\%).

\subsection{Opportunities and Problems faced by Women Digital Entrepreneurs during COVID-19}

Opportunities and Problems variables are analysed using Chi-Square test.

\subsubsection{Opportunities of Women Entrepreneurs in their online business during COVID-19}

COVID-19 pandemic unlocked opportunities for Women Entrepreneurs in achieving their significant growth in online business. Online business is the exclusive way of the future for Women Entrepreneurs, as this pandemic have created uncertainty, caution and social distancing which identified need of E-Business for Women Entrepreneurs. The main advantage of online business is Convenience to both entrepreneurs and customers. 
- Low cost : Online business eliminates the need of physical store front. Marketing through social media is cost-effective than promoting offline. These cost savings reflect in lower price of their product and increases the sales of business.

- Wider customer base: At this time of pandemic customers are more attracted towards online shopping, as it removes direct contacts with the sellers.

- Easier to scale-up : As online business does not require more physical space like shop floors and employees, it also eliminates the need of opening a new stores or branches in another location as it reach wider place in global market.

- Cash less transaction : In online business, women entrepreneurs receives payment digitally like card payment, net banking and cash on delivery. Thus Women Entrepreneurs receives instant transactions without payment delay.

Table 2 Opportunities of Women Entrepreneurs in online business during COVID-19

\begin{tabular}{|l|c|c|c|}
\hline \multicolumn{1}{|c|}{ Opportunities } & No. of Respondents & Percentage (\%) & $\begin{array}{c}\text { Cumulative } \\
\text { Percentage(\%) }\end{array}$ \\
\hline Lower cost & 12 & 12.0 & 12.0 \\
\hline Saves time & 13 & 13.0 & 25.0 \\
\hline Convenient and safe & 24 & 24.0 & 49.0 \\
\hline Ease access of Customer data & 9 & 9.0 & 58.0 \\
\hline Wider coverage of Customer & 12 & 12.0 & 70.0 \\
\hline 24/7 Working Service & 5 & 5.0 & 75.0 \\
\hline Removal of Middlemen & 2 & 2.0 & 77.0 \\
\hline Offer wider products & 2 & 2.0 & 79.0 \\
\hline Elderly consumers prefers online & 8 & 8.0 & 87.0 \\
\hline Shopping & 7 & 7.0 & 94.0 \\
\hline Easier to scale up & 6 & 6.0 & 100.0 \\
\hline Instant Feedback from customers & 100 & 100.0 & \\
\hline Total & & & \\
\hline
\end{tabular}

(Source: Primary Data)

\section{Interpretation:}

From the above table 2.1, shows that convenient and safe (24\%) is major opportunity faced by Women Digital Entrepreneurs during COVID-19. Next opportunity is time saving (13\%) followed by wider coverage of customers (12\%) and Low cost of setting up (12\%). Moderate favourable opportunities they have are ease access of customer data (9\%), elderly consumer prefers online shopping (8\%), easier to scale-up (7\%), instant feedback from customers $(6 \%)$ and 24/7/365 working 95\%). Less favourable opportunities are removal of middle men (2\%) and offer of wider products $(2 \%)$.

\subsubsection{Interrelationship Between Experience in Online Business and Opportunities of Women Digital Entrepreneurs during COVID-19 \\ Variables:}

Dependent Variable: Opportunities of Women Digital Entrepreneurs during COVID-19

Independent Variable: Marital Status of Women Digital Entrepreneurs.

\section{Hypothesis:}

$\mathrm{H}_{0}$ : There is no evidence for significant relationship between Education Qualification and Opportunities for Women Digital Entrepreneurs during COVID-19.

$\mathrm{H}_{1}$ : There is evidence for significant relationship between Education Qualification and Opportunities for Women Digital Entrepreneurs during COVID-19. 
Table 3 Relationship Between Experience in Online Business and Opportunities of Women Digital Entrepreneurs during COVID-19

\begin{tabular}{|c|c|c|c|c|c|c|c|c|c|c|c|c|}
\hline \multirow[b]{2}{*}{$\begin{array}{c}\text { Experienc } \\
\text { e in Online } \\
\text { Business }\end{array}$} & \multicolumn{11}{|c|}{ Opportunities of Women Entrepreneurs in online business during COVID-19 } & \multirow[b]{2}{*}{$\begin{array}{c}\text { Tota } \\
1\end{array}$} \\
\hline & $\begin{array}{l}\text { Lowe } \\
\mathbf{r} \text { cost }\end{array}$ & \begin{tabular}{|c|} 
Save \\
$S$ \\
time
\end{tabular} & $\begin{array}{l}\text { Convinien } \\
t \text { and safe }\end{array}$ & $\begin{array}{c}\text { Ease } \\
\text { access of } \\
\text { Custome } \\
r \text { data }\end{array}$ & \begin{tabular}{|c} 
Wider \\
coverage \\
of \\
Custome \\
r \\
\end{tabular} & $\begin{array}{c}24 / 7 \\
\text { Workin } \\
\text { g } \\
\text { Service }\end{array}$ & $\begin{array}{c}\text { Removal of } \\
\text { Middleme } \\
n\end{array}$ & $\begin{array}{c}\text { Offer } \\
\text { wider } \\
\text { product } \\
\text { s }\end{array}$ & \begin{tabular}{|c|} 
Elderly \\
consumer \\
s pefers \\
online \\
Shopping \\
\end{tabular} & \begin{tabular}{|c} 
Easie \\
$\mathbf{r}$ to \\
scale \\
up \\
\end{tabular} & \begin{tabular}{|c|} 
Instant \\
Feedback \\
from \\
customer \\
s \\
\end{tabular} & \\
\hline o-1 year & 12 & 13 & 5 & 0 & 3 & 4 & 1 & 0 & 4 & 4 & 3 & 49 \\
\hline $\begin{array}{l}1 \text { year- } 3 \\
\text { years }\end{array}$ & 0 & 0 & 17 & 3 & 0 & 0 & 0 & 0 & 1 & 1 & 0 & 22 \\
\hline $\begin{array}{l}3 \text { years- } \\
5 \text { years }\end{array}$ & 0 & 0 & 2 & 6 & 9 & 1 & 1 & 2 & 3 & 0 & 2 & 26 \\
\hline $\begin{array}{l}\text { Above } 5 \\
\text { years }\end{array}$ & 0 & 0 & 0 & 0 & 0 & 0 & 0 & 0 & 0 & 2 & 1 & 3 \\
\hline Total & 12 & 13 & 24 & 9 & 12 & 5 & 2 & 2 & 8 & 7 & 6 & 100 \\
\hline
\end{tabular}

(Source: Primary Data)

Table 4

\begin{tabular}{|l|c|c|c|}
\hline \multicolumn{4}{|c|}{ Chi-Square Tests } \\
\hline & Value & df & $\begin{array}{c}\text { Asymptotic } \\
\text { Significance (2-sided) }\end{array}$ \\
\hline Pearson Chi-Square & $118.399^{\mathrm{a}}$ & 30 & .000 \\
\hline Likelihood Ratio & 116.431 & 30 & .000 \\
\hline Linear-by-Linear Association & 9.431 & 1 & .002 \\
\hline N of Valid Cases & 100 & & \\
\hline a. 38 cells (86.4\%) have expected count less than 5. The minimum expected count is .06. \\
\hline
\end{tabular}

(Source: Primary Data)

\section{Interpretation:}

Table value for 30 Degree of Freedom @ 1\% level is 40.256

Since the Calculated value of Chi-Square is 118.39 , which is greater than the (>) the Table Value (40.256) of Chi-Square. $\mathrm{H}_{0}$ is Rejected. Hence, There is a evidence for significant relationship between Experience in online business and Opportunities of Women Digital Entrepreneurs during COVID-19.

\section{Conclusion}

The $\mathrm{P}$ value of variable $(0.00)$ is less than $(<) 0.01$ at $1 \%$ level of significance. Hence, $\mathrm{H}_{0}$ is Rejected. The result indicate that there is a significance relationship between Experience in Online business and Opportunities of Women Digital Entrepreneurs during COVID-19.

\subsection{Problems Faced by Women Digital Entrepreneurs during COVID-19}

Major challenges faced by Women entrepreneurs during COVID-19 pandemic are finding new customers, retaining existing customers, financial shortage, self doubt and fear, Government law and regulations, and lack of education and knowledge about internet. 
Table 5 Problems faced by Women Entrepreneurs in online business during COVID-19

\begin{tabular}{|l|c|c|c|}
\hline \multicolumn{1}{|c|}{ Problems } & No. of respondents & Percentage (\%) & $\begin{array}{c}\text { Cumulative } \\
\text { Percentage (\%) }\end{array}$ \\
\hline Finding new customers & 27 & 27.0 & 27.0 \\
\hline $\begin{array}{l}\text { Fear like Personal health \& safety, } \\
\begin{array}{l}\text { Uncertainty about continuation of } \\
\text { business, etc. }\end{array}\end{array}$ & 26 & 26.0 & 53.0 \\
\hline $\begin{array}{l}\text { Retention of Existing Customers } \\
\text { Lack of finance to grow the business }\end{array}$ & 16 & 16.0 & 69.0 \\
\hline Increase in Competition & 3 & 8.0 & 77.0 \\
\hline Self Doubt & 6 & 3.0 & 80.0 \\
\hline $\begin{array}{l}\text { Goverment laws, Policies and regulations } \\
\text { during Lockdown }\end{array}$ & 1 & 6.0 & 87.0 \\
\hline Supply Chain Distruptions & 4 & 1.0 & 91.0 \\
\hline Lack of social support & 3 & 4.0 & 94.0 \\
\hline $\begin{array}{l}\text { Lack of information, education and } \\
\text { Knowledge about Internet }\end{array}$ & 4 & 3.0 & 98.0 \\
\hline Lack of Customer Orders & 1 & 4.0 & 99.0 \\
\hline Limited Access to Workforce & 100 & 1.0 & 100.0 \\
\hline Total & & 1.0 & \\
\hline
\end{tabular}

(Source : Primary data)

\section{Interpretation}

From the above table, it is found that major problem faced by Women Digital Entrepreneurs during COVID-19 is finding new customers (27\%) and fear like personal health and safety $(26 \%)$. Moderate challenges faced by Women Digital Entrepreneurs are retention of existing customers $(16 \%)$, lack of finance $(8 \%)$, self doubt and lack of confidence $(6 \%)$, supply chain disruptions (4\%), lack of education and knowledge about internet (4\%), fear from competitors $(3 \%)$, and lack of social support (3\%). Lower challenges faced by Women Digital Entrepreneurs are Government laws, policies and regulations (1\%), lack of customer orders $(1 \%)$, and limited access to workforce (1\%).

\subsubsection{Interrelationship Between Kind of E-Business and Problems faced by Women Digital Entrepreneurs in Online business during COVID-19.}

\section{Variables:}

Dependent Variable: Problems faced by Women Digital Entrepreneurs during COVID-19

Independent Variable: Kinds of online business run by Women Entrepreneurs

\section{Hypothesis:}

$\mathrm{H}_{0}$ : There is no evidence for Significant relationship between Kind of E-Business running by Women Entrepreneurs and Problems faced by Women Digital Entrepreneurs in Online business during COVID-19.

$\mathrm{H}_{1}$ : There is a evidence for Significant relationship between Kind of E-Business running by Women Entrepreneurs and Problems faced by Women Digital Entrepreneurs in Online business during COVID-19. 
Opportunities and Problems of Women Digital Entrepreneurs in India during Covid-19 Pandemic

\subsubsection{Relationship Between Kind of E-Business and Problems faced by Women Digital Entrepreneurs in Online business during COVID-19.}

Table 6

\begin{tabular}{|c|c|c|c|c|c|c|c|c|c|c|c|c|c|}
\hline & Problem & is faced by & Women I & Entrep & preneurs in & onlir & ne business & s during $\mathbf{C}$ & OVID- & & & & \\
\hline $\begin{array}{l}\text { Kinds of } \\
\text { E- } \\
\text { Business }\end{array}$ & $\begin{array}{c} \\
\\
\\
\text { Finding } \\
\text { new } \\
\text { custom } \\
\text { ers } \\
\end{array}$ & $\begin{array}{c}\text { Fear like } \\
\text { Personal } \\
\text { health \& } \\
\text { safety, } \\
\text { Uncertain } \\
\text { about } \\
\text { continuati } \\
\text { on of } \\
\text { business, } \\
\text { etc. } \\
\end{array}$ & \begin{tabular}{|c|} 
\\
\\
Retentio \\
n of \\
Existing \\
Custom \\
ers
\end{tabular} & \begin{tabular}{|} 
Lack \\
of \\
financ \\
e to \\
grow \\
the \\
busine \\
ss \\
\end{tabular} & $\begin{array}{c}\text { Increase } \\
\text { in } \\
\text { Competiti } \\
\text { on }\end{array}$ & $\begin{array}{c} \\
\text { Self } \\
\text { Dou } \\
\text { bt }\end{array}$ & $\begin{array}{c}\text { Governm } \\
\text { ent laws, } \\
\text { Policies } \\
\text { and } \\
\text { regulatio } \\
\text { ns during } \\
\text { Lockdow } \\
\text { n }\end{array}$ & \begin{tabular}{|c} 
Supply \\
Chain \\
Distrupti \\
ons
\end{tabular} & $\begin{array}{c}\text { Lack } \\
\text { of } \\
\text { social } \\
\text { suppo } \\
\text { rt } \\
\end{array}$ & $\begin{array}{c}\text { Lack of } \\
\text { informati } \\
\text { on, } \\
\text { education } \\
\text { and } \\
\text { Knowled } \\
\text { ge about } \\
\text { Internet }\end{array}$ & \begin{tabular}{|c|} 
\\
Lack of \\
Custom \\
er \\
Orders
\end{tabular} & \begin{tabular}{|c} 
Limited \\
Access \\
to \\
Workfo \\
rce \\
\end{tabular} & $\begin{array}{c}\text { Tot } \\
\text { al } \\
\\
\end{array}$ \\
\hline \begin{tabular}{|l|} 
Online \\
Marketin \\
$\mathrm{g}$
\end{tabular} & 4 & 3 & 3 & 2 & 1 & 1 & 0 & 1 & 1 & 1 & 0 & 0 & 17 \\
\hline $\begin{array}{l}\text { Clothing } \\
\text { and } \\
\text { Accessori } \\
\text { es }\end{array}$ & 5 & 4 & 2 & 0 & 1 & 1 & 0 & 0 & 0 & 0 & 0 & 0 & 13 \\
\hline \begin{tabular}{|l} 
Online \\
teaching
\end{tabular} & 2 & 3 & 4 & 1 & 1 & 1 & 0 & 1 & 0 & 1 & 0 & 0 & 14 \\
\hline \begin{tabular}{|l} 
Food and \\
Catering \\
services
\end{tabular} & 5 & 4 & 1 & 1 & 0 & 1 & 0 & 1 & 1 & 1 & 0 & 0 & 15 \\
\hline \begin{tabular}{|l|} 
Beauty \\
cosmetics \\
and \\
services
\end{tabular} & 1 & 5 & 3 & 2 & 0 & 1 & 1 & 1 & 1 & 1 & 1 & 1 & 18 \\
\hline $\begin{array}{l}\text { online } \\
\text { Consulta } \\
\text { ncy } \\
\text { services }\end{array}$ & 0 & 1 & 1 & 0 & 0 & 1 & 0 & 0 & 0 & 0 & 0 & 0 & 3 \\
\hline \begin{tabular}{|l|} 
Travellin \\
g and \\
Tourism \\
Services
\end{tabular} & 1 & 1 & 0 & 0 & 0 & 0 & 0 & 0 & 0 & 0 & 0 & 0 & 2 \\
\hline \begin{tabular}{|l|} 
online \\
Professio \\
nal \\
Services \\
\end{tabular} & 1 & 0 & 0 & 0 & 0 & 0 & 0 & 0 & 0 & 0 & 0 & 0 & 1 \\
\hline \begin{tabular}{|l|} 
Online \\
Health \\
Care \\
Services
\end{tabular} & 1 & 1 & 0 & 0 & 0 & 0 & 0 & 0 & 0 & 0 & 0 & 0 & 2 \\
\hline \begin{tabular}{|l|} 
Event \\
Organizin \\
$\mathrm{g}$
\end{tabular} & 2 & 1 & 0 & 0 & 0 & 0 & 0 & 0 & 0 & 0 & 0 & 0 & 3 \\
\hline $\begin{array}{l}\text { Web } \\
\text { Designin } \\
\mathrm{g}\end{array}$ & 2 & 1 & 1 & 0 & 0 & 0 & 0 & 0 & 0 & 0 & 0 & 0 & 4 \\
\hline $\begin{array}{l}\text { Retail } \\
\text { selling }\end{array}$ & 1 & 1 & 0 & 1 & 0 & 0 & 0 & 0 & 0 & 0 & 0 & 0 & 3 \\
\hline $\begin{array}{l}\text { online } \\
\text { Gifts } \\
\text { sellers }\end{array}$ & 1 & 1 & 1 & 0 & 0 & 0 & 0 & 0 & 0 & 0 & 0 & 0 & 3 \\
\hline $\begin{array}{l}\text { online } \\
\text { bidding } \\
\text { services }\end{array}$ & 1 & 0 & 0 & 1 & 0 & 0 & 0 & 0 & 0 & 0 & 0 & 0 & 2 \\
\hline Total & 27 & 26 & 16 & 8 & 3 & 6 & 1 & 4 & 3 & 4 & 1 & 1 & 100 \\
\hline
\end{tabular}

(Source: Primary Data) 
Table 7

\begin{tabular}{|l|c|c|c|}
\hline \multicolumn{3}{|c|}{ Chi-Square Tests } \\
\hline & Value & Df & $\begin{array}{c}\text { Asymptotic } \\
\text { Significance (2-sided) }\end{array}$ \\
\hline Pearson Chi-Square & $59.822^{\mathrm{a}}$ & 143 & 1.000 \\
\hline Likelihood Ratio & 62.444 & 143 & 1.000 \\
\hline Linear-by-Linear Association & 3.135 & 1 & .077 \\
\hline N of Valid Cases & 100 & & \\
\hline
\end{tabular}

(Source: Primary Data)

\section{Interpretation:}

Table value for 143 Degree of Freedom @ 5\% level is 171.907

Since the Calculated value of Chi-Square is 59.822, which is less than the $(<)$ the Table Value (171.907) of Chi-Square. $\mathrm{H}_{0}$ is Accepted. Hence, There is no evidence for significant relationship between Kind of E-Business running by Women Entrepreneurs and Problems faced by Women Digital Entrepreneurs in Online business during COVID-19.

\section{Conclusion}

The $\mathrm{P}$ value of variable (1.000) is greater than (>) 0.05 at $5 \%$ level of significance. Hence, $\mathrm{H}_{0}$ is Accepted. The result indicate that there is no significance relationship between Kind of EBusiness running by Women Entrepreneurs and Problems faced by Women Digital Entrepreneurs in Online business during COVID-19.

\subsection{Prediction of level of risk of Women Digital Entrepreneurs in the $3^{\text {rd }}$ Quarter of COVID-19}

Level of risk predicted by Women Entrepreneurs in their online business in the $3^{\text {rd }}$ quarter of 2021 with the variables are listed below. These are analysed by descriptive statistics.

Table 8 Failure to repay debt

\begin{tabular}{|l|c|c|c|}
\hline \multicolumn{1}{|c|}{ Opinion } & $\begin{array}{c}\text { No. of } \\
\text { Respondents }\end{array}$ & Valid Percentage & Cumulative Percentage \\
\hline High Risk & 39 & 39.0 & 39.0 \\
\hline Moderate risk & 35 & 35.0 & 74.0 \\
\hline Lower Risk & 26 & 26.0 & 100.0 \\
\hline Total & 100 & 100.0 & \\
\hline
\end{tabular}

(Source: Primary Data)

It is observed that 39 percent of the respondents have High Level of risk, 35 percent have Moderate level of risk and 26 percent have Low level of risk in the $3^{\text {rd }}$ Quarter of COVID-19.

Table 9 Failure to borrow funds

\begin{tabular}{|l|c|c|c|}
\hline \multicolumn{1}{|c|}{ Opinion } & $\begin{array}{c}\text { No. of } \\
\text { Respondents }\end{array}$ & Valid Percentage & Cumulative Percentage \\
\hline High Risk & 34 & 34.0 & 34.0 \\
\hline Moderate risk & 46 & 46.0 & 80.0 \\
\hline Lower Risk & 20 & 20.0 & 100.0 \\
\hline Total & 100 & 100.0 & \\
\hline
\end{tabular}

(Source: Primary Data)

It is observed that 34 percent of the respondents have High Level of risk, 46 percent have Moderate level of risk and 20 percent have Low level of risk in the $3^{\text {rd }}$ Quarter of COVID-19. 
Opportunities and Problems of Women Digital Entrepreneurs in India during Covid-19 Pandemic

Table 10 Insufficient customer demand

\begin{tabular}{|l|c|c|c|}
\hline \multicolumn{1}{|c|}{ Opinion } & No. of Respondents & Valid Percentage & Cumulative Percentage \\
\hline High Risk & 31 & 31.0 & 31.0 \\
\hline Moderate risk & 41 & 41.0 & 72.0 \\
\hline Lower Risk & 28 & 28.0 & 100.0 \\
\hline Total & 100 & 100.0 & \\
\hline
\end{tabular}

(Source: Primary Data)

It is observed that 31 percent of the respondents have High Level of risk, 41 percent have Moderate level of risk and 28 percent have Low level of risk in the $3^{\text {rd }}$ Quarter of COVID-19.

Table 11 Loss of qualified work force

\begin{tabular}{|l|c|c|c|}
\hline \multicolumn{1}{|c|}{ Opinion } & No. of Respondents & Valid Percentage & Cumulative Percentage \\
\hline High Risk & 37 & 37.0 & 37.0 \\
\hline Moderate risk & 40 & 40.0 & 77.0 \\
\hline Lower Risk & 23 & 23.0 & 100.0 \\
\hline Total & 100 & 100.0 & \\
\hline
\end{tabular}

(Source: Primary Data)

It is observed that 37 percent of the respondents have High Level of risk, 40 percent have Moderate level of risk and 23 percent have Low level of risk in the $3^{\text {rd }}$ Quarter of COVID-19.

Table 12 Disruption in supply chain

\begin{tabular}{|l|c|c|c|}
\hline \multicolumn{1}{|c|}{ Opinion } & No. of Respondents & Valid Percentage & Cumulative Percentage \\
\hline High Risk & 25 & 25.0 & 25.0 \\
\hline Moderate risk & 42 & 42.0 & 67.0 \\
\hline Lower Risk & 33 & 33.0 & 100.0 \\
\hline Total & 100 & 100.0 & \\
\hline
\end{tabular}

(Source: Primary Data)

It is observed that 25 percent of the respondents have High Level of risk, 42 percent have Moderate level of risk and 33 percent have Low level of risk in the $3^{\text {rd }}$ Quarter of COVID- 19.

Table 13 Predictions of Level of Risks in the $3^{\text {rd }}$ Quarter of 2021

\begin{tabular}{|l|c|c|c|c|c|c|}
\hline \multicolumn{1}{|c|}{ Predictions } & $\mathbf{N}$ & Minimum & Maximum & Mean & Std. Deviation & Ranks \\
\hline Failure to repay debts & 100 & 1.00 & 3.00 & 1.8700 & .79968 & V \\
\hline Failure to borrow funds & 100 & 1.00 & 3.00 & 1.8600 & .72502 & III \\
\hline $\begin{array}{l}\text { Insufficient customer } \\
\text { demand }\end{array}$ & 100 & 1.00 & 3.00 & 1.9700 & .77140 & II \\
\hline $\begin{array}{l}\text { Loss of qualified work } \\
\text { force }\end{array}$ & 100 & 1.00 & 3.00 & 1.8600 & .76568 & III \\
\hline $\begin{array}{l}\text { Disruption in supply chain } \\
\text { Valid N (listwise) }\end{array}$ & 100 & 1.00 & 3.00 & 2.0800 & .76118 & I \\
\hline
\end{tabular}

(Source: Primary Data)

\section{Interpretation:}

The Mean score of Failure to repay debts in the $3^{\text {rd }}$ Quarter of 2021 is 1.87 with Standard Deviation is 0.79968 . The standard Deviation is more than $1 / 3$ of the mean. It concludes that Women Digital Entrepreneurs predict high level of risk in repayment of debt in the $3^{\text {rd }}$ Quarter of 2021.

The Mean score of Failure to borrow funds in the $3^{\text {rd }}$ Quarter of 2021 is 1.86 with Standard Deviation is 0.72502 . The standard Deviation is more than $1 / 3$ of the mean. It concludes that Women Digital Entrepreneurs predict high level of risk in Failure to borrow funds in the $3^{\text {rd }}$ Quarter of 2021. 
The Mean score of Insufficient customer demand in the $3^{\text {rd }}$ Quarter of 2021 is 1.97 with Standard Deviation is 0. 77140. The standard Deviation is more than $1 / 3$ of the mean. It concludes that Women Digital Entrepreneurs predict high level of risk in decreasing customer demand for their products in the $3^{\text {rd }}$ Quarter of 2021.

The Mean score of Loss of qualified work force in the $3^{\text {rd }}$ Quarter of 2021 is 1.8600 with Standard Deviation is 0.76568. The standard Deviation is more than $1 / 3$ of the mean. It concludes that Women Digital Entrepreneurs predict high level of risk in Loss of qualified work force in the $3^{\text {rd }}$ Quarter of 2021.

The Mean score of Disruption in supply chain in the $3^{\text {rd }}$ Quarter of 2021 is 2.0800 with Standard Deviation is 0. .76118. The standard Deviation is less than $1 / 3$ of the mean. It concludes that Women Digital Entrepreneurs predict low level of risk in Disruption in supply chain in the $3^{\text {rd }}$ Quarter of 2021.

On the Basis of Mean Value, ranks assigned by the respondents. Failure to repay debts has higher level of risk prediction among the respondents in the $3^{\text {rd }}$ Quarter of 2021.followed by Insufficient customer demand, Failure to borrow funds, and Loss of qualified work force.

Disruption in supply chain has lowest level of risk prediction among the respondents in the $3^{\text {rd }}$ Quarter of 2021.

\section{FINDINGS}

This study reports that most respondents of Women Digital Entrepreneurs belongs to the age group of 20- 30 years and have qualification of Under Graduate. Most of the Women Entrepreneurs are married and have less than one year of experience. Maximum number of respondents of Women Digital Entrepreneurs are Sole-Proprietors and have Micro level business.

From the above analysed data, it shows that by accepting the Null Hypothesis (H0) Average age of the respondents belong to the age group of 20 years- 30 Years, Average years of Experience of the respondents have in E-Business is 1year - 3 Years, Average number of respondents are Retailers and Average size of the online business run by Women Entrepreneur is small scale Business. By rejecting the Null Hypothesis, Average Marital Status of the Respondents are not Spinster, Average Education Qualification of the Respondents does not have Under Graduate Degree and Average kind of Business run by the Women Entrepreneurs is not Beauty products and cosmetics.

Major opportunity faced by Women Entrepreneurs in online business during COVID-19 is convenient and safe (24\%). Next opportunity is time saving (13\%) followed by wider coverage of customers (12\%) and Low cost of setting up (12\%). Moderate favourable opportunities they have are ease access of customer data (9\%), elderly consumer prefers online shopping (8\%), easier to scale-up (7\%), instant feedback from customers (6\%) and 24/7/365 working 95\%). Less favourable opportunities are removal of middle men $(2 \%)$ and offer of wider products (2\%). Major challenges faced by Women Entrepreneurs in online business is finding new customers $(27 \%)$ and fear like personal health and safety (26\%). Moderate challenges faced by Women Digital Entrepreneurs are retention of existing customers (16\%), lack of finance (8\%), self doubt and lack of confidence (6\%), supply chain disruptions (4\%), lack of education and knowledge about internet (4\%), fear from competitors (3\%), and lack of social support (3\%). Lower challenges faced by Women Digital Entrepreneurs are Government laws, policies and regulations (1\%), lack of customer orders (1\%), and limited access to workforce (1\%).

The interrelationship between Experience in online business and Opportunities of Women Digital Entrepreneurs during COVID-19, Chi-Square clearly indicates that There is a evidence 
for significant relationship between Experience in online business and Opportunities of Women Digital Entrepreneurs during COVID-19.

The interrelationship between Kind of E-Business and Problems faced by Women Digital Entrepreneurs in Online business during COVID-19, Chi-Square clearly indicates that there is no significance relationship between kind of E-Business running by Women Entrepreneurs and Problems faced by Women Digital Entrepreneurs in Online business during COVID-19.

Predicting the level of risk of Women Entrepreneurs in online business in the $3^{\text {rd }}$ quarter of 2021 using descriptive statistics, predicts that high level of risk in repayment of debt, in failure to borrow funds, in decreasing customer demand for their products, in Loss of qualified work force and Low level of risk in Disruption in supply chain in the $3^{\text {rd }}$ Quarter of 2021.

\section{SUGGESTIONS}

Many women entrepreneurs in online business are of opinion that they are in lack of technological skills and training because of which they are not able to survive in the market. Hence, Government should conduct training programmes, conferences, trade fairs, and exhibition with regard to new sales techniques, marketing techniques etc.

For increasing the participation of Women Entrepreneurs in online business, Government has to provide more fund as well as train more trainers so that the opportunity, survivability, profitability and sustainability of their business activities can

Reduction of barriers associated with Women Entrepreneurs, those who suffer during and after COVID-19 pandemic by accessing them health care facilities, paid sick leave etc.

Promote investment in Women Entrepreneurs skills and online training during COVID-19 and encourage them in up skilling of start-up workers.

Make flexible in administrative for start-ups by implementing simplified procedure and accelerating transitions to e-government and reduce regulatory uncertainty both during and after the COVID-19 pandemic.

Promoting net-work developments by linking job seekers and start-ups and those facilitators access to international markets.

Women Entrepreneurs has to be provided training along with promoting displaced workers and life-long learning which can facilitate transition from employment to Entrepreneurship.

It is recommended that the government has to provide more funds, develop adequate infrastructure as well as make arrangement of training to encourage Women entrepreneurs to participate in online business so that the opportunity, survivability, profitability and sustainability of their business activities can occur.

\section{CONCLUSIONS}

Women Entrepreneurs are threatened by COVID-19 pandemic, means they are at risk of unemployment, lack of productivity and loss of revenue. This crisis has shown vast growth in digital business ventures. In order to meet demand of consumers, during COVID-19 pandemic as there is a fear of uncertainty and physical interaction, Women Entrepreneurs are more likely to adapt to a digital technology. This pandemic has caused Digital business transformation among Women Entrepreneurs, depending upon their creativity, innovation and government growth-oriented economic policy. This paper aims to provide insights of opportunities of Women Entrepreneurs and challenges faced by them during COVID-19 crisis.

This paper reveals that by analysing Chi-Square, states that there is a evidence for significant relationship between Experience in online business and Opportunities of Women Digital Entrepreneurs during COVID-19. And there is no significance relationship between 
kind of E-Business running by Women Entrepreneurs and Problems faced by Women Digital Entrepreneurs in Online business during COVID-19.

This shows that Experience pays a way for opportunities among Women Entrepreneurs in Digital business to survive, grow and fearless in COVID-19 pandemic situation they face. The challenge most often faced by Women Digital Entrepreneurs during pandemic is finding new customers (27\%) and fear like personal health and safety (26\%). This paper demonstrates that there is a significant increase in Women Entrepreneurs in digital platforms who conduct their business online due to restrictions instituted by governments which has impacted on customer's demand. Women Entrepreneurs shift their business from traditional method to digital method because they believe that they can face the future survival with confidence.

\section{REFERENCES}

[1] Susmitha Kunchaparthi (2021)- "Impact of COVID 19 on E-Commerce"- Journal of Interdisciplinary Cycle Research- Volume XII, Issue IX, September/2020 ISSN NO: 00221945- PP. 1161- 1165.

[2] Risqo M. Wahid, Diah Isnaini Asiati (2021)- "Women MSMEs and Covid-19: Social Media Marketing as a Survival Strategy"- International Journal of Innovative Science and Research Technology - ISSN No:-2456-2165- Volume 6, Issue 2- PP.368- 378- www.ijisrt.com.

[3] Salome K. Kaberia, Stephen M.A. Muathe (2021) - "Effect of Covid-19 Pandemic on Performance of Women Owned Micro, Small and Medium Enterprises in Kenya"- International Journal of Social Science Studies- Volume. 9, No. 1- ISSN 2324-8033 E-ISSN 2324-8041 http://ijsss.redfame.com

[4] Anam Bhatti, Hamza Akram, Hafiz Muhammad Basit, Ahmed Usman Khan, Syeda Mahwish Raza, Naqvi, Muhammad Bilal (2020)- "E-commerce trends during COVID-19 Pandemic"International Journal of Future Generation Communication and Networking- ISSN: 22337857- Vol. 13, No. 2- pp.1449-1452.

[5] Luca Koltai, Virag Zsar, Andrea Petroczi (2020)- "COVID-19 and female entrepreneurs throughout Europe"- HETFA Research Institute Ltdhttps://www.researchgate.net/publication/344665139

[6] Madhavilatha Sangem (2020)- "Challenges for Women Entrepreneurs in the Wake of COVID 19 Pandemic"- Journal of Interdisciplinary Cycle Research- ISSN NO: 0022-1945- Volume XII, Issue XI- PP. 279-284

[7] Tatiana S Manolova, Candida G Brush, Linda F Edelman, (2020) "Pivoting to stay the course: How women entrepreneurs take advantage of opportunities created by the COVID 19 pandemic "- International Small Journal : Researching Entrepreneurship - Volume 38, issue 6PP. 481-491- https://journals.sagepub.com/doi/full/10.1177/0266242620949136

[8] Saipriya Salla, (2020)- "How will COVID 19 Affect Women Entrepreneurs?”- Internet- Source: http://www.ipsnews.net/2020/07/will-COVID 19-affect-women-entrepreneurs/

[9] Siti Masayu Rosliah Abdul Rashid, Fathimah Hassan and Kurshiah Ahamad (2020)- "Post Covid-19 Online Business Strategies by Small-Scale Entrepreneurs in Malaysia- International Journal of Academic Research in Business and Social Science- ISSN: 2222-6990http://dx.doi.org/10.6007/IJARBSS/v10-i9/7635

[10] Madhobi Hossain, Mayeesha Fairuz Rahman (2018)- "Social Media and the Creation of Entrepreneurial Opportunity for Women"- DOI: 10.5923/j.mm.20180804.02

[11] Akhila Pai H (2018)-“Digital Startups and Women Entrepreneurship : A Study on status of Women Entrepreneurs in India" - e ISSN 2348 -1269, Print ISSN 2349-5138- VOLUME 5, ISSUE 4- http://ijrar.com/ 
Opportunities and Problems of Women Digital Entrepreneurs in India during Covid-19 Pandemic

[12] Eunice Mukolwe, Dr. Jacqueline Korir (2016)- "Social Media and Entrepreneurship: Tools, Benefits, and Challenges. A Case Study of Women Online Entrepreneurs on Kilimani Mums Marketplace on Facebook", International Journal of Humanities and Social Science, Vol. 6, No. 8, ISSN 2220-8488 (Print), 2221-0989 (Online), PP. 248-256, www.ijhssnet.com.

[13] Impact of Covid-19 on Women Entrepreneurs- Women Entrepreneurship knowledge Hub

[14] Leila Mivehchi (2019)- "The Role of Information Technology in Women Entrepreneurship (The Case of E-Retailing in Iran) "- 3rd World Conference on Technology, Innovation and Entrepreneurship (WOCTINE)- www.sciencedirect.com

[15] Dr. Bimal Anjum, Rajesh Tiwari (2012) - "Role of Information Technology in Women Empoerment"- International Journal of Multidisciplinary Management Studies- Vol.2 Issue 1ISSN 2249-8834, PP 226-223 